\title{
Research on education reform of improving occupation quality of college students
}

\author{
Mei dan ${ }^{1, a}$, Gong yuan ${ }^{2, b}$, Zhang hongjie ${ }^{1, c}$, Wen meng ${ }^{1, d}$
}

1.College of resource and environmental engineering, Wuhan University of science and technology, Wuhan, Hubei, 430081

2.Dean's Office of Wuhan University of science and technology, Wuhan,Hubei,430081

ameidan@wust.edu.cn, ${ }^{\mathrm{b}}$ gongyuan@wust.edu.cn, ${ }^{\mathrm{c}}$ zhanghongjie@wust.edu.cn, ${ }^{\mathrm{d}}$ 307802877@qq.com

Keywords: Higher education; Cultivation of talents; Occupation quality; Cultivation approach ; Education reform

\begin{abstract}
With the economic and social development, national demand for talent level is rising. College students not only have solid professional knowledge and practical ability, but also have excellent occupational quality.Professional quality plays an important role in the process of personal development and lifelong development. To effectively improve the quality of talents cultivation,higher education must pay attention to the cultivation of professional quality of undergraduates. Therefore, occupation quality training has been a problem that can not be ignored in college cultivating talents. Colleges and universities as the main camp of popular education, neglect the cultivation of occupation quality while steady focusing on teaching quality, mainly in lacking the concept of professionalism, deviating in the curriculum assessment system, weakening the practice teaching. To resolve these problems, we research on the three core elements about consciousness, knowledge, and practices, which are necessary for the occupation quality training, and explore the methods of the teaching reform to promote occupation quality, provided a theoretical basis for occupation quality training.

Occupational quality including professional ethics, spirit, attitude and professional skills, knowledge and behaviors is high-quality that people engaging in professional activity manifested, is a careering inherent requirement,is a code of conduct people need to comply with in social activities $^{[1]}$. Occupational quality has become the required characteristics when college students adapt to future careers and the "basic skills" when college students move to social, employment and entrepreneurship, $t$ contributions ${ }^{[2]}$. Colleges and universities as the important base for cultivating talents, should adapt to economic and social development gradually, and meet the social demand for occupational quality, so the reform of vocational literacy training is imperative.
\end{abstract}

\section{The main reason for college students lacking of professionalism}

Through follow-up survey of graduates, employers generally reflect the most graduates take a relatively long time to adapt to the changes in work and their own roles, resulting in reduced efficiency and delays, which exposed many other issues in professionalism education for universities indirectly, for example, literacy training career goal is not clear, and community awareness training quality dislocation, lack of necessary relation between education and employment,the lack of research for literacy and vocational education.

Chinese traditional teaching mode dictates. The traditional Chinese teaching mode is always around the examination, it concerned more about the students' test scores and grasp of theoretical 
knowledge, while ignoring the training of students' moral awareness, expression skills, communication skills ${ }^{[3]}$.Classroom majority takes "cramming", teachers standing on the podium to lecture, student being silent in class, lacking of communication with students, which result in the loss of student' awareness of the issue, and obliterate the student's personality, eventually lead to lower professionalism for students.

Thinking and understanding lag, lack of the guide for professionalism philosophy. People's thinking and understanding determines the degree of perception about objective things. Nowadays, whether teaching managers or teachers are lacking of the guide for professionalism philosophy, and focus solely on indoctrination of techniques in everyday teaching, enhancing the level of scientific knowledge, ignore the students' training of moral, ethical, professional quality, etc. Not to mention link the professionalism to the entire part of the integration of cultivating talents.

Oriented deviation for curriculum evaluation system. The current college curriculum evaluation system, mostly continues the assessment methods under examination-oriented education mode, all emphasizes on the course final exam, which result that the students develop bad habits "usual relaxed exam assault, "and often more review the learned knowledge in the last two weeks, do not get deep realization, lack of mutual authentication between theory and practice more, lose the enthusiasm and initiative in the learning process, and learning content is not well digested, not to mention the training of professionalism ${ }^{[4]}$.

Value theory, despise practice. "Value theory, despise practice" is the common problem of higher education. Judging from the personnel cultivating scheme, common professional theory class hours reach more than $70 \%$ of the total class hours, practice class hours are only about $25 \% .{ }^{[5]}$ And that, practice teaching is not very good implemented, performance in these:1)Experiment and internship "cheating on workmanship and materials" ,students complete the independent experiment which becomes people mutual experiment;(2)Practice condition of limited, some practical projects are limited by experimental equipment number, practice field and practice budgetary, these are difficult to implement;3internship units can't satisfy the requirements of practice reception, especially engineering colleges and universities to use state-owned large and medium-sized enterprises of the production site, due to security, confidentiality, etc, internship is limited.Therefore, students' practice teaching can't be guaranteed, students are short of practical knowledge, their occupation quality are less likely to get promoted.

\section{The way to cultivate college students' professional quality}

The cultivation of occupation quality is various the result of the interaction, which is the external performance of individual comprehensive ability, so we can be occupation quality as an organic system, that is to say "by the interaction and interdependence of the combination of several components of the organic whole with a specific function" ${ }^{\text {[6] }}$, it contains the moral edification, consciousness cultivation, knowledge increase, skills upgrading, etc. which can be summarized as awareness, knowledge, practice three big aspects, that is three elements, which through the coordinated development of various elements, finally make a good and orderly development of the whole system.

Consciousness element cultivation. Consciousness is a reflection of the human brain to objective things, it decides to individual behavior.Consciousness as an important part of occupation quality, should contain the lofty ideological and political quality, noble moral sentiment, high quality professional spirit, etc. The moral sentiment depends on everyone's code of conduct, as the saying 
goes" to do everything, you need firstly to be a upright person", Noble moral sentiment can not only show personal charm, more likely to get others' recognition at work; Professional spirit is the professional person to a kind of occupation, work attitude, including modern society engaged in labor need professional spirit and team work spirit, which have become the basic requirements of a qualified professional person ${ }^{[7]}$. Therefore ,the cultivation of the consciousness elements will be the key of the talents cultivation in colleges and universities.

Knowledge element training. Rich professional knowledge is the key to professional quality training, also is the foundation of the students' practical, professional operation, it includes the principle of clarity, work process and target of cognition, operation technology and familiar with the specification, etc. Individuals with the knowledge more rich, think of questions will be more comprehensive, and continuously strengthen knowledge reserves, increase the breadth and depth of knowledge, the more help to the cultivation of individual professional quality.

Practices training. Practice is the sole criterion for testing truth, and the only way changing the world. Practice is an important part of professional quality. The lever of professional quality depends on individual practice ${ }^{[8]}$. At present, employing concepts gradually transform from the education to the ability.When hiring employees, employers like problem solving ability more. We should take the cultivation of practical abilities as an entry point,strengthening students' practice and training opportunities, stimulating students' enthusiasm for the practice and improving students' practical ability.

\section{The measures on teaching reforms of students' cultivation of professional accomplishment}

Focusing on various elements of professional quality cultivation the talents cultivation in university has constantly updated Educational concepts, innovating teaching mode and improving the teaching methods[9]. The measures can be specifically implemented from the following aspects.Figure 1 shows the approach of improving occupation quality of college students.

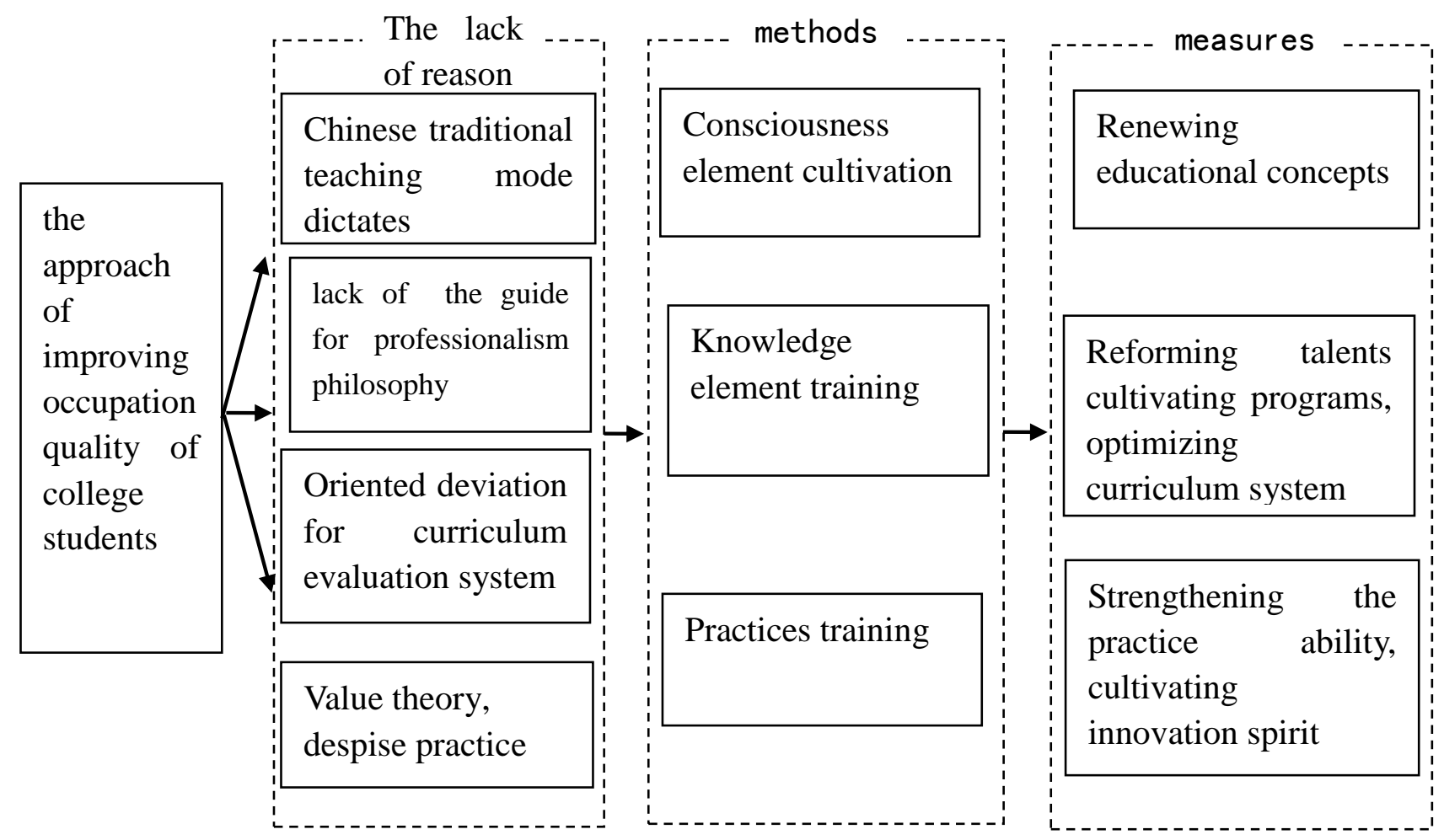

Figure. 1 sketch map of the approach of improving quality of college students 
Renewing educational concepts, and being merged into professional quality educational concepts. Updating education methods is the prerequisite and fundamental of both reform and development. The reform will achieve harmony and unification from top to bottom and be permeated in all aspects of cultivating talents only if it is well recognized. The platform explicitly requested:"To deepen educational reform system, the key is to upgrade the educational concepts, the core is to reform talents cultivating system ,the purpose is to improve the talents cultivating level" [9]. The most important problem of graduates' lack of professional is the imperfect understanding of the concepts of educating people.Therefore, Educational administrators and teachers should continuously renew concepts, be integrated into the concept of literacy education, and apply them to all aspects of teaching management and talents cultivating. Ideological consensus is the most important of occupation quality training. Reform the curriculum assessment system and improve teaching methods.

Reforming talents cultivating programs, optimizing curriculum system. Talents cultivating program is the programmatic document of talents cultivating. Reasonable program will be a great help in the students' occupation quality training. And occupation quality training philosophy needs to be reflected in the personnel training program ${ }^{[10]}$. First, reforming talents cultivating programs, increasing the proportion of experiments and practice teaching, improving students' practical ability; increasing the quality of education module, encouraging students to participate in scientific research projects, the second class and social activities. The students must complete the innovation education $^{[11]}$. Second, optimizing curriculum system, establishing a rational system of knowledge structure, introducing cutting-edge technology into the classroom, improving the students' humanities and expertise knowledge system, bringing occupation quality training into the curriculum system. According to students' needs for employment and work,courses related to employment guidance, the role of the workplace and other subjects should be offered for students. Integrating the influence of professionalism and training into daily teaching process.

Strengthening the practice ability, cultivating innovation spirit. Practice has become a growth in the use of students' professional knowledge, communication ability, cooperation consciousness training. To strengthen the students' practical ability training, optimize the practice teaching system systematically, based on the practice platform, increase students' practical hands-on opportunities; Add project innovation, designing experiment, cultivate students' ability to analyze and solve problems; Established on the basis of the project into practice platform, training students to the operation of the instruments, and allows students to realize the metalworking items according to oneself idea ; Encourage students to participate in all kinds of practice project, guides the student to participate in the actual project, to make the students understand the process of project research, increase work experience ${ }^{[12]}$; Based on graduation design (paper), to strengthen the students' comprehensive application in professional knowledge, through the collection of data, discuss and solve problems, state the question-and-answer session, exercise the students' various aspects ability; Enhancing university-enterprise cooperation to get the practice teaching into the unit of choose and employ persons, lets the student really took to the internship, sink to settle real practice teaching into practice, implementing the double tutorial system, hire enterprises technical engineers to be the practice teacher, to do a good job of practice teaching.

Set up training platform to cultivate college students' professional quality. Professional training of the university students with professional education as the main body, with an emphasis on 
practical ability training, relying on "classroom teaching and practice, post project" as the carrier, fully integrating and using existing resources, by using the way of theory with practice, set up classroom teaching and outside the classroom training platform, science and technology competition and campus off-campus practice and post project platform, to give students more opportunities of social contact, in the process of practice constantly strengthen students' communication, solidarity and cooperation spirit, improve students' practice ability and innovation ability, promote the improvement of students' professional quality.

\section{References}

[1] Lin Yang. Study on the professional quality education of college students and its evaluation [J]. Education and vocation, 2010 (24): 179.

[2] Liu Xingeng, etc. On modern development of professional quality of college students[J]. Journal of Hunan University of science and technology (Social Science Edition), 2010 (5): 129.

[3] Cheng Guangwen, etc. Around the industry needs reform of personnel training model in engineering exploration[J]. Journal of Wuhan University of science and technology (Social Science Edition), 2012 (4): 458.

[4]Zhang Jiwen:College students' knowledge of information literacy tutorials.Nanjing university press.2007.

[5]Lin Ruiqing:College students' occupation quality.Renmin university of Chain publishing house. 2014.

[6] Qian xuesen. Theory of systems engineering [M]. Hunan: Hunan science and technology press, 1982:10.

[7]Yang Haoying:Professional quality education:the new direction of talents cultivation in higher education[J].Journal of Hennan Institute of Science and Technology (Social Sciences Education),2014(8):005.

[8]Zhang Xiling:On the approaches and methods of cultivating university students' professional quality[J].Journal of Henan mechanical and electrical engineering college,2008(16).

[9] National education reform and development of long-term planning programs (2010-2020) [DB/OL]. http://www.moe.gov.cn/publicfiles/business/htmlfiles/moe/moe_838/201008/93704.html, 2014-09-05.

[10]Ren Yanming:The importance and cultivation strategy research of college students' occupation quality[J].Education and Vocation,2010(17):046.

[11]Peng Juan:On professional accomplishment cultivation target and structural elements in higher vocational education[J].Higher education forum,2012(08):39.

[12]Wu Dayong:College students'occupation quality.Beijing institute of technology press.2011. 